\title{
Coverage Of Pak-Us Relations In Elite Press Of Pakistan And Us During The Democratic Government Of Pakistan People's Party; March 2008 To February 2012 (Media \& Foreign Policy Perspective)
}

\author{
Zahid Yousaf $(\mathrm{PhD})^{1,}$ Ehtisham $\mathrm{Ali}^{2}$ \\ I'Assistant Professor/Head, Centre for Media and Communication Studies, University of Gujrat, Post code \\ 50700 Gujrat, Punjab, Pakistan) \\ ${ }^{2}$ M Phil Fellow Centre for Media and Communication Studies, University of Gujrat, Post code 50700 Gujrat, \\ Punjab, Pakistan)
}

\begin{abstract}
The present research "Pak-US Relations in Elite Press of Pakistan and US during the Democratic Government of Pakistan People's Party; March 2008 to February 2012 (Media \& Foreign Policy Perspective)" is focused to study the foreign policies of Pakistan and the United States of America in the editorials of the elite press during the democratic government of Pakistan People's Party that came into the power after the general elections in 2008.In this study two elite English newspapers from United States and Pakistan were selected for the study, "New York Times" from US and "The Daily Dawn" from Pakistan from March 2008 to February 2012. The current study is intends to find out the relationship between Pakistan and US during the democratic government in Pakistan. The main purpose behind this study is to uncover the experience of the foreign policy making by the governments of the states under study and the role played by the mass media at present. The theoretical framework for the study in hand refers to the Agenda Setting Theory as the study is focused to determine the 'Media Agenda' of the press of selected countries and to determine the different incidents relating to the present study. In this study the contents of the editorials of the selected newspapers related to Pak-US relations are considered. The findings of the study conclude that the Pakistani media in general and the US media in particular have not followed the view points of the respective governments regarding the foreign policy of the respective countries.
\end{abstract}

Keywords: Democratic, Elite Press, Pakistan, United States

\section{Introduction}

The present paper is an attempt to find out the relationship between Pakistan and United States of America in the elite press of both Pakistan and America during the democratic government of Pakistan Peoples Party that won the general elections in 2008 and formed a coalition government with Pakistan Muslim League (Nawaz) along with some other parties like Mutahida Qoumi Movement (MQM), Awami National Party (ANP), Jamiat Uluma e Islam Fazal ur Rehman, JUI (F) etc, Later PML (N) and JUI (F) left the alliance and the other majority group Pakistan Muslim League (Quaid e Azam) joined the governmental alliance later. All these parties joined the Pakistan Peoples Party to strengthen democracy and to promote democratic culture in the country.

This study is very important in various aspects because it includes various developments between the two states in the democratic government of Pakistan Peoples Party, in the government of Peoples Party various important events occurred regarding the Pak-US relations. The famous Kerry Lugar Bill was presented in the government of Peoples Party, the bill faced too much controversy and criticism by the people from different walks of life was passed in the October of 2009 . The bill included the approval of granting $\$ 7.5$ billion non military aid to Pakistan. This bill clearly showed the United States distrust in Pakistan's military command.

In 2011 the killings of two Pakistani citizens by a CIA agent Raymond Davis in Lahore increased the tensions. Davis claimed that both came to rob him and he killed them in self defense, he was taken into custody by the police for killing two civilians; however US officials claimed that he was entitled to the diplomatic immunity and he must be released immediately by Pakistan. This incident was given a lot of coverage by Pakistani media but Raymond Davis was later released by Pakistan and was sent back to United States.

In the same year in May 2011, Osama Bin Ladin Al Qaeda's head was killed in an operation conducted by US forces in Abbottabad, Pakistan.US President Barrack Obama claimed in his statement after the operation that the information pertaining to the operation in Abbottabad was a hidden operation and was not shared with Pakistan army, However Inter Services Intelligence (Pakistan's secret agency) claimed that the Abbotabad operation was a joint operation conducted by Pakistan and US, a claim which was blatantly denied by the President of Pakistan Asif Ali Zardari. 
A clash emerged again when almost 24 Pakistani soldiers were killed by the US Army attack on a Pakistani check post at Salala. As a result of the attack by US Pakistani government ordered US to evacuate its air bases that were being used by the US forces. The Pakistani government also closed the NATO supplies for United States and its allies in Afghanistan. As result of the NATO supply blockade by Pakistan, various political parties of Pakistan along with the military command of the country met and held discussions on restoring NATO supplies. The issue was also discussed in the parliament as this incident was taken as an attack on the sovereignty of Pakistan. The US top leadership and the diplomats also tried to reduce the friction. At last Pakistan agreed to reopen the key supply routes into Afghanistan in July, the supply was opened after US Secretary of State Hillary Clinton said she was sorry for the loss of the lives in an air attack on Pakistani soldiers.

The study is focused on the relationships between the Pakistan and United States of America in the democratic government of Pakistan People's Party and its allies, the study intends to know about the relations that were made between the two states after a long time period of General Pervaiz Musharraf's military regime. Although there was the government of PML (Q) that was said to be a democratic government when General Musharraf was holding his office as President of Pakistan but at the same time he was also holding the office as Chief of Army Staff as well and was influencing the government of that time as well so, his government's period is mostly given the name as the dictator's regime. The true democracy in Pakistan is claimed by all the political parties after the general elections in 2008. So, in this study Pak-US relations are focused to study during the democratic government in Pakistan from March 2008 to February 2012.

This study shows the Pak-US Relations in the media and foreign policy perspective that how the media of Pakistan and United States has portrayed Pak-US relations in their respective newspapers further more the study also shows the media's relations with the respective governments.

\section{Hypotheses:}

Main hypothesis: The press of Pakistan and America does not support the foreign policy of their respective countries.

Sub Hypothesis-1: American press does not follow the US's foreign policy regarding Pak-US relations.

Sub Hypothesis-2: Pakistani press does not follow the Pakistan's foreign policy regarding Pak-US relations.

Sub Hypothesis-3: American press has given minimum favorable coverage regarding Pak-US relations.

Sub Hypothesis-4: Pakistani press has given minimum favorable coverage regarding Pak-US relations.

\section{Literature Review}

The literature regarding the coverage of the media and foreign policy relations, and the news media contains a lot of related studies especially regarding the topic under discussion that is the Pak-US relations. A number of well known scholars have worked under the umbrella of media and foreign policy, Mughees (1993) citing Larson (1984) says that some studies have observed the images of the foreign nations, particularly the images of the actual or potential enemies, as placed in the media of the selected countries.

This study is focused to discuss that how the US and the Pakistani elite English press portrayed Pak-US relations in their editorials and what relationship exists with the official standpoint of the policy makers of the selected newspapers from both the countries.

In the context of media and foreign policy Cohen's work that is known as "The Press and Foreign Policy" is considered as a pioneer study by the scholars of media and foreign policy and this study is cited in most of the studies that are related to the media foreign policy relationship (Mughees, 1997). Cohen who is considered as the pioneer of the media and foreign policy study has called attention to the influence of the press on US foreign policy and analyzed the ways in which the government officials on one hand and non-government policy makers on the other hand both are influenced by the press, and in response to this sometimes they use media to further their policy motives. Cohen (1963) further noted that in a democracy, the anxiety is unavoidable between the officials and the journalists.

The people now rely on the mass media for all type of information about the international affairs to a great deal. Therefore the media plays an important role in this situation in forming the mass perceptions and the related thoughts regarding other nations. Various studies have found that the exposure to the news coverage increases knowledge of the people on one hand whereas it can also influence the public opinion of a respective nation towards the foreign nations significantly (Albritton \& Manheim, 1983, 1985; Perry, 1985, 1987). Such perceptions can also have some important implications in certain areas ranging from the nature of the personal contacts and interactions among people of various nations to the mass media related attitudes related to the foreign policy of the states to practice of the public diplomacy (Manheim, 1991, 1994; Bartels, 1995). So, this shows that is not much surprising that the major political and mass media related actors in the international scenario often take on their considerable efforts in this regard in order to mold the content of media coverage of the incidents according to their own wishes or the needs. 
Several studies by the well known scholars of media consider that the American media do not necessarily support its governmental policy because, in a free press system, the press is not believed to be a catalyst in the inter-governmental dealings. Some of the studies (Becker, 1977 \& Mughees, 1992) propose that the New York Times opposed US foreign policy towards Pakistan if it was unfavorable to India.

It is assumed that there is also need to analyze the relationship between the foreign coverage of the events by media and foreign policy making aspect. The reason for this is that now all the events including the foreign events are dealt by the media through the media coverage and by foreign policy makers through the conception, modification and implementation of the policies that are made by the policy makers. Further more, the findings on the media and foreign policy perspective of several authors like Livingston (1997), Livingston and Eachus (1995), Jacobsen (1996 \& 2000) and Mermin (1997) reveal the impact of the news media on the foreign policy decision-making process.

Foreign policy in the Western democracies as in the case of the United States, is drawn upon the idea of a predetermined national interest of the country, with the end of the Cold War main concern of America's national interest that was stopping the spread of communism was over, yet the challenge was still there that was about the new definition of national interests. As Hoge (1993) illustrates that "there is not yet an articulated official framework for American foreign policy in a still new post-Cold War world". Livingston and Eachus (1995) both are having the same point of the views that reporters have been found to the routinely turn to officials as the news sources. Jacobsen (2000) noted the impact of the media coverage on the foreign conflict management in relation to different phases related to violence of the conflict concluding that there is the direct impact of the media on foreign policy making in various aspects. Mermin (1997) argues that all the time media has been used by the powerful elites to put pressure over the government and the officials further he also noted that the coverage follow the actions of the policy makers.

The America's foreign policies are always drawn around a set of priorities that are determined in relation to the degree of importance of the distinguished national interests, which are also determined by the levels of risk to the US national security. Media is also believed to raise the importance of tangential matters over more substantial concerns in the cases of policy uncertainty and the lack of political leadership as well. Power concentration also varies according to the dimension of desired concern. When it comes to the policymaking then those involved in the process posses a different level of the power and tries to create a policy that they must be subjected to a bargaining interaction "between a set of the subsystems present in the government" (Robinson, 2001). Further more Nossek, (2004) citing Herman and Chomsky argue that the journalists are mostly willing to compromise professional norms to the national interest. However their findings show that journalists' behavior is are actually context dependent.

Ehtisham (2012) state that Pakistani media do not fully support the foreign policy of Pakistan on various issues of national interest and sovereignty, Pakistan's media is not bound to favor the foreign policy of Pakistan all the time.

After reviewing the literature, it is therefore concluded that several studies by the well known researchers and scholars show that media of the countries supports the government policies but on the other hand there are also the evidences as result of the studies like those of (Becker, 1977 \& Mughees, 1993) show that the media of any country do not necessarily support the view point of the country or the government.

\section{Theoretical Foundation}

\section{Agenda Setting:}

The theory employed in this paper is agenda setting theory, E.M. Rogers, J.W. Dearing and D. Bregman (1993) after reviewing more than 200 articles on the topic referred the three related agendas that are the media agenda, the public agenda, and the policy agenda cited in (Miller, 2004) The first one is the media agenda that involves the set of the topics that are addressed by media sources. The second is the public agenda that is related to the set of the topics that the members of the public believe is very important and finally, there is the policy agenda that represents all the issues that the decision-makers (legislators) believe are primarily salient.

The present study "Pak-US Relations in Elite Press of Pakistan and US during the Democratic Government of Pakistan People's Party; March 2008 to February 2012 (Media \& Foreign Policy Perspective)" intends to determine the 'Media Agenda' of the press of Pakistan and United States. It intends to examine the priorities of the press in this regard and also to determine the frequency of the coverage of selected issues by the press of Pakistan and US.

In the study in hand, the researcher has tried to study that how the press of Pakistan and US has covered the selected issues from March 2008 to February 2012 in the democratic government in Pakistan and tried to set the desired agenda of the news organizations and how has influenced in setting the agenda in the foreign policy perspective moreover it is also determined that how media of the selected countries has favored 
or disfavored the foreign policy of the respective countries. Through this study it is also tried to determine that how the media play its role of agenda setting to influence the country's important issues.

\section{Methodology}

The employed methodology for this paper is content analysis. Sarantakos (1998) describe content analysis "As a method of the social research, content analysis is a documentary method that aims at both qualitative and quantitative analysis of the content".

\section{Universe:}

The universe includes all the editorials of the selected newspapers i.e. US newspaper The New York Times and Pakistani newspaper Daily Dawn. The editorials which are related to the above mentioned A, B, C, D and E categories with reference to Pak-US relations during the selected time period i.e. from March 2008 to February 2012 are selected as the Universe for this study.

\section{Sampling:}

In this research the entire universe (The editorials of New York Times and Daily Dawn) is considered as sample as the editorials of the selected newspapers are to be analysed from March 2008 to February 2012.

\section{Unit of Analysis:}

The unit of analysis in this study is considered to be the words, sentences, paragraphs or even an entire editorial, which indicate the presence of one of the categories, published in both Pakistani and US newspapers.

\section{Time Period:}

All the editorials of the two newspapers New York Times and Daily Dawn from March 2008 to February 2012 are included for content analysis in this study.

\section{Categories of Analysis:}

The categories are the heart of the content analysis. The collection of the data becomes possible and easy through the construction of the categories. A category in content analysis is a set of criteria or a measure, which are integrated round a theme or a value (Sarantakos, 1998: 281).

A) Pakistan's Democratic Government's stance on Pak-US Relations.

B) Obama Administration's stance on Pak-US Relations during the Democratic Government of Pakistan.

C) US attacks in Pakistani territory as a factor on Pak-US relations.

D) Influence of India, China, Russia and Iran on Pak-US relations.

E) Pak-US alliance and relations regarding war on terrorism.

\section{Directions of Contents:}

For the measurement of the directions of selected editorial contents of both the newspapers New York Times and Daily Dawn i.e. under the study, the researcher agree to the method that Berelson (1952) given the name as "the totality of the impression". This totality of impression was actually used to establish the "direction" of the communication. To find out the direction of the contents of the editorials of selected newspapers, the data would be graded on a three point scale i.e. given below.

\section{Favorable/Supportive (+):}

Any editorial is considered "Supportive" $(+)$ and is favorable regarding the study.

\section{Unfavorable/Opposite (-):}

Any editorial is believed as unfavorable or critical (-), which is negative in tone and its general attitude is unfavorable regarding the study.

\section{Neutral/Balance (0):}

Any editorial is judged as neutral (0) or balanced if the content of the editorial is indistinguishable and it emphasis on either of the favorable or unfavorable aspects of an issue or if it displays a balance of both favorable and unfavorable arguments regarding the study. 


\section{Data Analysis And Interpretation}

Total Editorials of New York Times and Daily Dawn March 2008- February 2012

\begin{tabular}{|l|l|l|}
\hline Newspaper & New York Times & Daily Dawn \\
\hline Percentage & 31.92 & 68.08 \\
\hline Number of Editorials & 98 & 209 \\
\hline
\end{tabular}

Table 1

Table 1 indicates the total editorials of New York Times and the Daily Dawn on Pak-US relations coverage from March 2008- February 2012.

The total number of editorials of the two newspapers New York Times and Daily Dawn regarding Pak-US relations are 307 in number from March 2008- February 2012, out of these editorials 98(31.92\%) are published in New York Times whereas 209(68.08\%) are published in Daily Dawn.

Editorials of New York Times and Daily Dawn from March 2008- February 2012

\begin{tabular}{|c|c|c|c|}
\hline \multirow{8}{*}{$\underset{y}{\mathscr{C}}$} & \multicolumn{3}{|c|}{ NEWSPAPER } \\
\hline & & New York Times & Daily Dawn \\
\hline & 2008 & $25(27.78)$ & $65(72.22)$ \\
\hline & 2009 & $25(35.71)$ & $45(64.29)$ \\
\hline & 2010 & $28(36.84)$ & $48(63.16)$ \\
\hline & 2011 & $14(27.45)$ & $37(72.55)$ \\
\hline & 2012 & $6(30.00)$ & $14(70.00)$ \\
\hline & Total & $98(31.92)$ & $209(68.08)$ \\
\hline
\end{tabular}

Table 2

Table 2 indicates the year by year of the editorials of New York Times and the Daily Dawn on Pak-US relations from March 2008- February 2012.

In 2008 New York Times published 25(27.78\%) editorials on Pak-US relations where as Daily Dawn has given 65(72.22\%) editorials regarding the Pak-US relations, in 2009 New York Times published 25(35.71\%) editorials on Pak-US relations where as Daily Dawn has given 45(64.29\%) editorials regarding the Pak-US relations, in 2010 New York Times published 28(36.84\%) editorials on Pak-US relations where as Daily Dawn has given $48(63.16 \%)$ editorials regarding the Pak-US relations,

in 2011 New York Times published 14(27.45\%) editorials on Pak-US relations where as Daily Dawn has given 37(72.55\%) editorials regarding the Pak-US relations whereas in 2012 New York Times has published 6(30.00\%) editorials on Pak-US relations where as Daily Dawn has given 14(70.00\%) editorials regarding the Pak-US relations. From March 2008 to February 2012 New York Times has published 98(31.92\%) editorials on Pak-US relations whereas Daily Dawn has given 209(68.08\%) editorials regarding the Pak-US relations.

Editorials of New York Times March 2008- February 2012

\begin{tabular}{|l|l|l|l|l|l|l|}
\hline \multirow{5}{*}{$\approx$} & \multicolumn{7}{|c|}{ CATEGORY } \\
\cline { 2 - 7 } & & A & B & C & D & E \\
\cline { 2 - 7 } & $\mathbf{2 0 0 8}$ & $0(0.00)$ & $12(48.00)$ & $4(16.00)$ & $2(8.00)$ & $7(28.00)$ \\
\cline { 2 - 7 } & $\mathbf{2 0 0 9}$ & $0(0.00)$ & $9(36.00)$ & $9(36.00)$ & $5(20.00)$ & $2(8.00)$ \\
\cline { 2 - 7 } & $\mathbf{2 0 1 0}$ & $0(0.00)$ & $13(46.42)$ & $9(32.14)$ & $2(7.14)$ & $4(14.28)$ \\
\cline { 2 - 7 } & $\mathbf{2 0 1 1}$ & $0(0.00)$ & $10(71.42)$ & $2(14.28)$ & $0(0.00)$ & $2(14.28)$ \\
\cline { 2 - 7 } & $\mathbf{2 0 1 2}$ & $0(0.00)$ & $4(66.66)$ & $1(16.66)$ & $0(0.00)$ & $1(16.66)$ \\
\hline & Total & $0(0.00)$ & $48(48.98)$ & $25(25.51)$ & $9(9.18)$ & $16(16.32)$ \\
\hline
\end{tabular}

Table 3

Table 3 indicates the editorials year wise and also show that how much editorials falls in each category A, B, C, D and E. Here A, B, C, D and E represent the following.
A) Pakistan's Democratic Government's stance on Pak-US Relations.
B) Obama Administration's stance on Pak-US Relations during the Democratic Government of Pakistan.
C) US attacks in Pakistani territory as a factor on Pak-US relations.
D) Influence of India, China, Russia and Iran on Pak-US relations.
E) Pak-US alliance and relations regarding war on terrorism.

In year 2008 in category A there is no editorial, in category B there are $48 \%$ editorials, in category $\mathrm{C}$ there are $16 \%$ editorials, in category D there are $8 \%$ editorials and in category E there are $28 \%$ editorials. In year 2009 in category A there is no editorial, in category B there are 36\%editorials, in category $\mathrm{C}$ there are $36 \%$ editorials, in category D there are $20 \%$ editorials and in category E there are $8 \%$ editorials. In year 2010 in category A there 
is no editorial, in category B there are $46.42 \%$ editorials, in category $\mathrm{C}$ there are $32.14 \%$ editorials, in category D there are $7.14 \%$ editorials and in category E there are $14.28 \%$ editorials. In year 2011 in category A there is no editorials, in category B there are $71.42 \%$ editorials, in category C there are $14.28 \%$ editorials, in category D there is no editorials and in category E there are $14.28 \%$ editorials. In year 2012 in category A there are $0 \%$ editorials, in category B there are $66.66 \%$ editorials, in category $\mathrm{C}$ there are $16.66 \%$ editorials, in category D there is no editorials and in category E there are 16.66\% editorials. From March 2008 to February 2012 overall total show that there are $0 \%$ editorials in category A, in category B there are $48.98 \%$ editorials, in category C there are $25.51 \%$ editorials, in category $\mathrm{D}$ there are $9.18 \%$ editorials and in category $\mathrm{E}$ there are $16.32 \%$ editorials.

Categories and Directions of Editorials of New York Times from March 2008- February 2012

\begin{tabular}{|c|c|c|c|c|c|c|c|c|c|c|c|c|c|c|c|}
\hline & \multicolumn{3}{|c|}{ A } & \multicolumn{3}{|c|}{ B } & \multicolumn{3}{|c|}{ C } & \multicolumn{3}{|c|}{ D } & \multicolumn{3}{|c|}{ E } \\
\hline & $0(0$ & & & 48( & 98) & & $25(2$ & .51) & & & & & $16(1$ & .32) & \\
\hline 苞 & 总 & 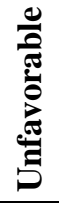 & 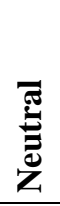 & 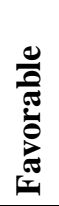 & 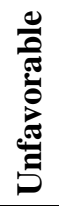 & $\begin{array}{l}\overline{\mathbb{T}} \\
\bar{E} \\
\bar{Z}\end{array}$ & 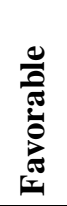 & 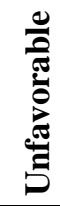 & $\begin{array}{l}\bar{\pi} \\
\bar{E} \\
z\end{array}$ & 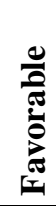 & 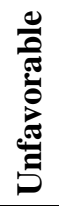 & $\begin{array}{l}\bar{T} \\
\bar{E} \\
\bar{Z}\end{array}$ & 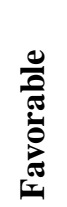 & 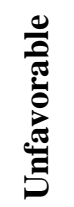 & $\begin{array}{l}\bar{\pi} \\
\bar{E} \\
\bar{Z}\end{array}$ \\
\hline No & 0 & 0 & 0 & 9 & 21 & 18 & 1 & 13 & 11 & 2 & 3 & 4 & 0 & 8 & 8 \\
\hline$\%$ & $\begin{array}{l}0.0 \\
0\end{array}$ & $\begin{array}{l}0.0 \\
0\end{array}$ & $\begin{array}{l}0.0 \\
0\end{array}$ & $\begin{array}{l}18 . \\
75\end{array}$ & $\begin{array}{l}43 . \\
75\end{array}$ & $\begin{array}{l}37 . \\
50\end{array}$ & $\begin{array}{l}4.0 \\
0\end{array}$ & $\begin{array}{l}52 . \\
00\end{array}$ & $\begin{array}{l}44 . \\
00\end{array}$ & $\begin{array}{l}22 \\
22\end{array}$ & $\begin{array}{l}33 . \\
33\end{array}$ & $\begin{array}{l}44 . \\
44\end{array}$ & $\begin{array}{l}0.0 \\
0\end{array}$ & $\begin{array}{l}50 . \\
00\end{array}$ & $\begin{array}{l}50 . \\
00\end{array}$ \\
\hline
\end{tabular}

Table 4

Table 4 indicates the overall editorials of New York Times from March 2008 to February 2012. In the graph there is no editorial in category "A", 48.98\% in "B", $25.51 \%$ in "C", $9.18 \%$ in "D" and $16.32 \%$ in category "E". These categories are further divided into three directions favorable, unfavorable and neutral. In "A" there is no coverage of all directions. In " $\mathrm{B}$ " $18.75 \%$ editorials are favorable, $43.75 \%$ in unfavorable and $37.50 \%$ neutral directions. In category " $\mathrm{C}$ " $4 \%$ is favorable, $52 \%$ unfavorable and $44 \%$ neutral directions. In category " $\mathrm{D}$ " there is $22.22 \%$ in favorable, $33.33 \%$ in unfavorable direction and $44.44 \%$ in neutral direction. In category " $\mathrm{E}$ " there is no editorials in favorable whereas $50 \%$ each in unfavorable and neutral directions respectively. Here we see that category "B" is given maximum space in editorials of New York Times that is about $48.98 \%$, then category " $\mathrm{C}$ " is in greater number after category " $\mathrm{B}$ " that is $25.51 \%$, then category " $\mathrm{E}$ " and "D" respectively in $16.32 \%$ and $9.18 \%$ and at the end there is category " $\mathrm{A}$ " that is given no coverage.

Editorials of Daily Dawn March 2008- February 2012

\begin{tabular}{|l|l|l|l|l|l|l|}
\hline \multicolumn{7}{|c|}{ CATEGORY } \\
\cline { 2 - 7 } & & A & B & C & D & E \\
\cline { 2 - 7 } & $\mathbf{2 0 0 8}$ & $22(33.84)$ & $0(0.00)$ & $10(15.38)$ & $11(16.92)$ & $22(33.85)$ \\
\cline { 2 - 7 } & $\mathbf{2 0 0 9}$ & $16(35.55)$ & $0(0.00)$ & $9(20.00)$ & $7(15.56)$ & $13(28.89)$ \\
\cline { 2 - 7 } & $\mathbf{2 0 1 0}$ & $17(35.42)$ & $2(4.17)$ & $7(14.59)$ & $9(18.75)$ & $13(27.08)$ \\
\cline { 2 - 7 } & $\mathbf{2 0 1 1}$ & $26(70.27)$ & $0(0.00)$ & $3(8.10)$ & $1(2.70)$ & $7(18.91)$ \\
\cline { 2 - 8 } & $\mathbf{2 0 1 2}$ & $5(35.71)$ & $0(0.00)$ & $4(28.58)$ & $1(7.14)$ & $4(28.58)$ \\
\hline & Total & $86(41.14)$ & $2(0.95)$ & $33(15.79)$ & $29(13.87)$ & $59(28.22)$ \\
\hline
\end{tabular}

Table 5

In year 2008 in category A there are $33.84 \%$ editorials, in category B there are $0 \%$ editorials, in category $\mathrm{C}$ there are $15.38 \%$ editorials, in category $\mathrm{D}$ there are $16.92 \%$ editorials and in category $\mathrm{E}$ there are $33.85 \%$ editorials. In year 2009 in category A there are $35.55 \%$ editorials, in category B there are $0 \%$ editorials, in category C there are $20 \%$ editorials, in category D there are $15.56 \%$ editorials and in category $\mathrm{E}$ there are $28.89 \%$ editorials. In year 2010 in category A there are $35.42 \%$ editorials, in category B there are $4.17 \%$ editorials, in category C there are $14.59 \%$ editorials, in category $\mathrm{D}$ there are $18.75 \%$ editorials and in category $\mathrm{E}$ there are $27.08 \%$ editorials. In year 2011 in category A there are 70.27\% editorials, in category B there are 0\%editorials, in category C there are $8.10 \%$ editorials, in category $\mathrm{D}$ there are $2.70 \%$ editorials and in category $\mathrm{E}$ there are $18.91 \%$ editorials. In year 2012 in category A there are $35.71 \%$ editorials, in category B there are $0 \%$ editorials, in category C there are $28.58 \%$ editorials, in category D there are $7.14 \%$ editorials and in category $\mathrm{E}$ there are $28.58 \%$ editorials. 
From March 2008 to February 2012 overall total show that there are $41.14 \%$ editorials in category A, in category B there are $0.95 \%$ editorials, in category C there are $15.79 \%$ editorials, in category D there are $13.87 \%$ editorials and in category $\mathrm{E}$ there are $28.22 \%$ editorials.

Categories and Directions of Editorials of Daily Dawn March 2008- February 2012

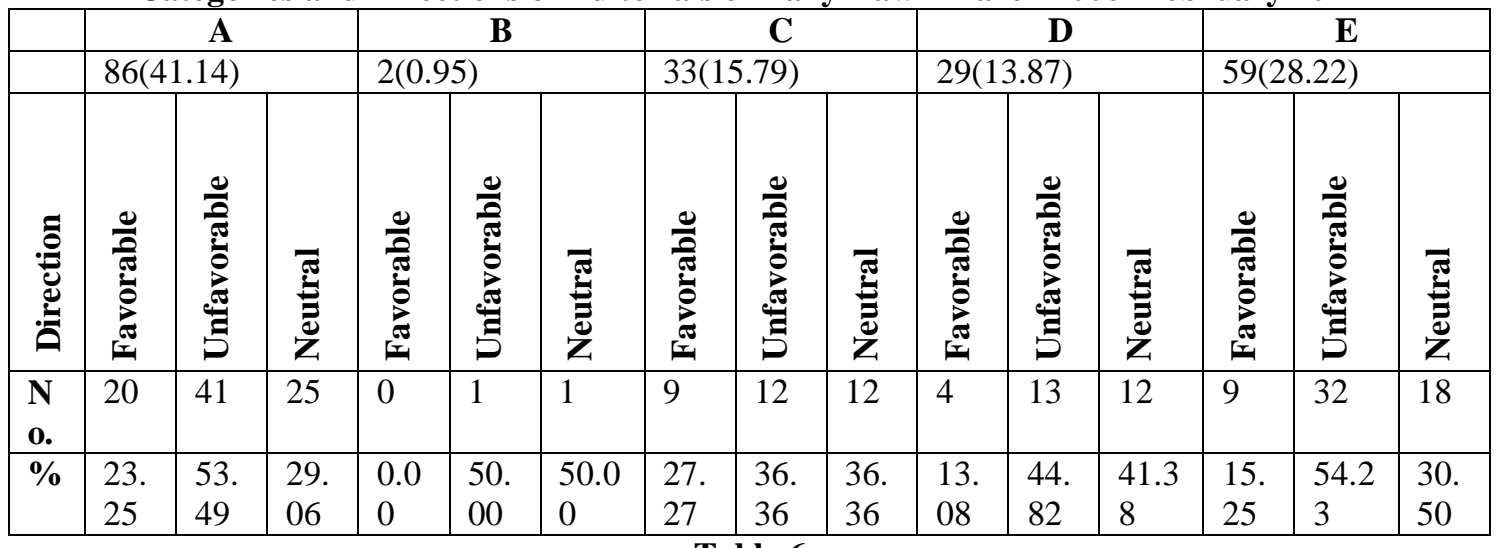

Table 6

Table 6 indicates the overall editorials of Daily Dawn from March 2008 to February 2012. In the graph there is $41.14 \%$ editorials in category "A", $0.95 \%$ in "B", $15.79 \%$ in "C", $13.87 \%$ in " $\mathrm{D}$ " and $28.22 \%$ in category " $\mathrm{E}$ ". These categories are further divided into three directions favorable, unfavorable and neutral. In "A" there is $23.25 \%$ in favorable, $53.49 \%$ unfavorable and $29.06 \%$ neutral directions. In "B" no editorials are favorable, $50 \%$ in unfavorable and $50 \%$ neutral directions. In category " $\mathrm{C}$ " $27.27 \%$ is favorable, $36.36 \%$ unfavorable and $36.36 \%$ neutral directions. In category " $\mathrm{D}$ " there is $13.08 \%$ in favorable, $44.82 \%$ in unfavorable direction and $41.38 \%$ in neutral direction. In category " $\mathrm{E}$ " there is $15.22 \%$ editorials in favorable whereas $54.23 \%$ and $30.50 \%$ in unfavorable and neutral directions respectively. Here we see that in category " $\mathrm{A}$ " is given maximum space in editorials of New York Times that is $41.14 \%$,then category " $\mathrm{E}$ " is in greater number after category " $\mathrm{A}$ " that is $28.22 \%$, then category " $\mathrm{C}$ " and " $\mathrm{D}$ " with $15.79 \%$ and $13.87 \%$ and at the end there is category " $\mathrm{B}$ " that is $0.95 \%$.

Comparison between the categories and Directions (in each category) of both New York Times and Daily

\begin{tabular}{|c|c|c|c|c|c|c|c|c|c|c|c|c|c|c|c|}
\hline \multicolumn{16}{|c|}{ Dawn March 2008- February 2012} \\
\hline Category & \multicolumn{3}{|c|}{$\mathbf{A}$} & \multicolumn{3}{|c|}{ B } & \multicolumn{3}{|c|}{$\mathbf{C}$} & \multicolumn{3}{|c|}{ D } & \multicolumn{3}{|c|}{$\mathbf{E}$} \\
\hline & 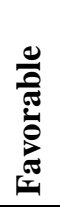 & 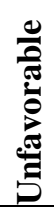 & $\begin{array}{l}\overline{0} \\
\bar{Z} \\
Z \\
Z\end{array}$ & 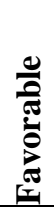 & 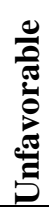 & Z & 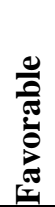 & 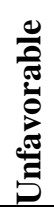 & 矛 & 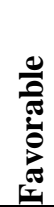 & 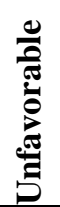 & 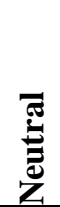 & 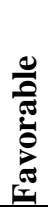 & 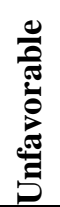 & $\begin{array}{l}\bar{\sigma} \\
\bar{Z} \\
\bar{Z}\end{array}$ \\
\hline $\begin{array}{l}\text { Editorials in } \\
\text { NY Time }\end{array}$ & 0 & 0 & 0 & 9 & 21 & 18 & 1 & 13 & 11 & 2 & 3 & 4 & 0 & 8 & 8 \\
\hline $\begin{array}{l}\text { Editorials in } \\
\text { Daily Dawn }\end{array}$ & 20 & 41 & 25 & 0 & 1 & 1 & 9 & 12 & 12 & 4 & 13 & 12 & 9 & 32 & 18 \\
\hline $\begin{array}{l}\text { Editorials in } \\
\text { a Direction }\end{array}$ & 20 & 41 & 25 & 9 & 22 & 19 & 10 & 25 & 23 & 6 & 16 & 16 & 9 & 40 & 26 \\
\hline $\begin{array}{l}\text { Editorials in } \\
\text { a Category }\end{array}$ & \multicolumn{3}{|l|}{86} & \multicolumn{3}{|l|}{50} & \multicolumn{3}{|l|}{58} & \multicolumn{3}{|l|}{38} & \multicolumn{3}{|l|}{75} \\
\hline
\end{tabular}

Table 7

Table 7 indicates the overall comparison of New York Times and Daily Dawn from March 2008 to February 2012 by comparing the editorials of both New York Times and Daily Dawn, the following results are found. In category "A" that is Pakistan's Democratic Government's stance on Pak-US Relations.; there are total 86 editorials for both New York Times and Daily Dawn. There are 20 in favorable direction, 41 in unfavorable and 25 in neutral directions. In category " $A$ " there is no editorial in New York Times whereas 20 in Daily Dawn in favorable direction, there is no editorial in New York Times whereas 41 in Daily Dawn in unfavorable direction and there is no editorial in New York Times whereas 25 are in Daily Dawn in neutral direction.

In category " $\mathrm{B}$ " that is Obama Administration's stance on Pak-US Relations during the Democratic Government of Pakistan; there are total 50 editorials for both New York Times and Daily Dawn. There are 9 in favorable direction, 22 in unfavorable and 19 in neutral directions. In category " $\mathrm{B}$ " there is 9 editorial in New 
York Times and no editorial in Daily Dawn in favorable direction, there is 21 editorial in New York Times whereas 1 in Daily Dawn in unfavorable direction and there is 18 editorial in New York Times whereas 1 in Daily Dawn in neutral direction.

In category "C" that shows US attacks in Pakistani territory as a factor on Pak-US relations; there are total 58 editorials for both New York Times and Daily Dawn. Out of these editorials there are 10 in favorable direction, 25 in unfavorable and 23 in neutral directions. In category " $\mathrm{C}$ " there is 1 editorial in New York Times whereas 9 in Daily Dawn in favorable direction, there is 13 editorial in New York Times whereas 12 in Daily Dawn in unfavorable direction and there is 11 editorial in New York Times whereas 12 in Daily Dawn in neutral direction.

In category " $D$ " which represents Influence of India, China, Russia and Iran on Pak-US relations; there are total 38 editorials for both New York Times and Daily Dawn. Out of these editorials there are 6 in favorable direction, 16 in unfavorable and 16 in neutral directions. In category " $\mathrm{D}$ " there is 2 editorial in New York Times whereas 4 in Daily Dawn in favorable direction, there is 3 editorial in New York Times 13 in Daily Dawn also in unfavorable direction and there is 4 editorial in New York Times whereas 12 in Daily Dawn in neutral direction.

In category "E" that is Pak-US alliance and relations regarding war on terrorism; there are total 75 editorials for both New York Times and Daily Dawn. Out of these editorials there are 9 in favorable direction, 40 in unfavorable and 26 in neutral directions. In category "E" there is no editorial in New York Times whereas 9 in Daily Dawn in favorable direction, there is 8 editorial in New York Times whereas 32 in Daily Dawn in unfavorable direction and there is 8 editorial in New York Times whereas 18 in Daily Dawn in neutral direction.

\section{Hypotheses findings:}

Main hypothesis: The press of Pakistan and America does not support the foreign policy of their respective countries.

Findings: The study proves the main hypothesis that the press of Pakistan and America does not support the foreign policy of their respective countries.

Sub Hypothesis-1: American press does not follow the US's foreign policy regarding Pak-US relations.

Findings: From the study sub hypothesis-1 is proved that American press does not follow the US's foreign policy regarding Pak-US relations.

Sub Hypothesis-2: Pakistani press does not follow the Pakistan's foreign policy regarding Pak-US relations.

Findings: From the study sub hypothesis-2 is proved that press does not follow the Pakistan's foreign policy regarding Pak-US relations.

Sub Hypothesis-3: American press has given minimum favorable coverage regarding Pak-US relations.

Findings: From the study sub hypothesis- 3 is proved that American press has given minimum favorable coverage regarding Pak-US relations.

Sub Hypothesis-4: Pakistani press has given minimum favorable coverage regarding Pak-US relations.

Findings: From the study sub hypothesis-4 is proved that Pakistani press has given minimum favorable coverage regarding Pak-US relations.

\section{Discussion}

This study "Pak-US Relations in Elite Press of Pakistan and US during the Democratic Government of Pakistan People's Party; March 2008 to February 2012 (Media \& Foreign Policy Perspective)" is an effort to know about the foreign policies of both the countries Pakistan and the United States of America in the democratic government of Pakistan Peoples Party.

In this study we conclude that the Pakistani newspaper has given more coverage than the US newspaper. The New York Times has shown greater percentage of unsatisfied behavior while portraying PakUS, after this New York Times has shown neutral behavior at second position which proves that US newspaper has not followed the U.S's foreign policy towards Pakistan because U.S foreign policy towards Pakistan is mostly criticized because of U.S's assistance to Pakistan due to the alliance on war against terror. The overall stance towards Pakistan in the newspaper New York Times shows unsatisfied behavior. It shows that US newspapers have not followed the US foreign policy while portraying its relations with Pakistan. The US newspaper has used the criticized Washington for the terms with Pakistan during the selected time period on various issues such as terrorism, US aid to Pakistan, presence of Osama Bin Lain in Pakistan and the blockade of NATO supply by Pakistan. US has given aid to Pakistan but it was portrayed in a very unsatisfied manner criticizing the U.S administration. It is also suggested that US should not have much soft corner for Pakistan.

In Daily Dawn an unsatisfied behavior is seen mostly, the issues are mostly discussed on the reality base the newspaper has criticized the Peoples Party government's policies on Pak-US relations due to its passive role on the major issues but on the other hand it has also appreciated the foreign policy of Pakistan where the paper thought that it is in the national interest and should be appreciated. Similar to the New York Times, Daily 
Dawn has not followed the government policy regarding Pak-US relations but on some important issues and decisions of the country's national interest and sovereignty the paper has followed the People's Party's government policy. It is also an important point that the Pakistani newspaper Daily Dawn has given more than double coverage to Pak-US relations than the US newspaper The New York Times on all the issues discussed during the selected time moreover study shows a greater concern of Daily Dawn regarding issues discussed than the New York Times. The overall study of the editorials of Pakistani newspaper Daily Dawn also shows that it has shown high level of unsatisfied behavior in the coverage of Pakistan's foreign policy regarding Pak-US relations in the Peoples Party democratic regime.

The study has well explained the topic "Pak-US Relations in Elite Press of Pakistan and US during the Democratic Government of Pakistan People's Party; March 2008 to February 2012 (Media \& Foreign Policy Perspective)", We can conclude that the media of both the countries Pakistan and United States is free to project the issues of national interest and nation's sovereignty so, the end result is that the media does not necessarily follow the government's view point regarding the foreign policy of the country and the same thing was examined in this paper.

[1] Albritton, R.B. and J.B. Manheim (1983) "News of Rhodesia: The Impact of a Public Relations Campaign” Journalism Quarterly 60: 622-8.

[2] Albritton, R.B. and J.B. Manheim (1985) "Public Relations Efforts for the Third World: Images in the News" Journal of Communication 35: 43-59.

[3] Ali, E. \& Shahid, K. (2012). Media \& Foreign Policy: A Study of Pak-US Relations in US and Pakistani Press, post 9/11 Era (20012011). Lap Lambert Academic Publishing.

[4] Becker, L.B. (1977). Foreign policy and press performance, Journalism Quarterly, 54, 364-368.

[5] Berelson, B. (1952). Content analysis in communication research. New York: Free Press.

[6] Cohen, B.C. (1963). The Press and foreign policy. Princeton: Princeton University Press.

[7] Hoge, J. (1993) "The End of Predictability" Media Studies Journal.

[8] Jacobsen, P. (1996) "National Interest, Humanitarianism or CNN: What triggers UN Peace Enforcement After the Cold War?" Journal of Peace Research. Vol. 33.

[9] Jacobsen, P. (2000) "Focus on the CNN Effect Misses the Point: The Real Media Impact on Conflict Management is Invisible and Indirect" Journal of Peace Research.

[10] Livingston and Eachus (1995) "humanitarian Crises and US Foreign Policy: Somalia and the CNN Effect Reconsidered" Political Communication. 12(4)

[11] Livingston, S. (1997) "Clarifying the CNN Effect: An Examination of Media Effects According to Type of Military Intervention" Research Paper.

[12] Mermin, J. (1997) "Television News and American Intervention in Somalia" Political Science Quarterly,

[13] Mermin, J. (1999) Debating war and peace. Media coverage of U.S intervention in the Post-Vietnam era, Princeton: Princeton University Press.

[14] Mughees-uddin. (1992). Editorial treatment of US foreign policy in the New York Times: The case of Pakistan (1980-90). Unpublished paper, presented at AEJMC convention in Montreal (Canada) on August, 7, 1992.

[15] Mughees-uddin. (1993). Elite press editorial farming of US foreign policy: The case of Pakistan and the New York Times, the Washington Post and the Loss Angeles Times (1980-1992). (Unpublished Ph.D. Thesis): The University of IOWA.

[16] Mughees-uddin. (1997) The case of Pakistan (1980-1990): Editorial Treatment of US Foreign Policy in The New York Times. Quarterly Journal, 4(2), 33-68.

[17] Manheim, J. B. (1991) All of the People, All the Time: Strategic Communication and American Politics. New York

[18] M.E. Sharp. Manheim, J. B. (1994) 'Strategic Public Diplomacy: Managing Kuwait’s Image during the Gulf Conflict', pp. 131-48

[19] Miller, K. (2004). Communication Theories: Perspectives, Processes, and Contexts, New York, McGraw-Hill

[20] Nossek, H. (2004). Our news and their news. Journalism, 5(3), 344-368.

[21] Perry, D.K. (1985) 'The Mass Media and Inference About Other Nations', Communication Research 12: 595-614.

[22] Perry, D.K. (1987) 'The Image Gap: How International News Affects Perceptions of Nations', Journalism Quarterly 64: 416-21.

[23] Robinson, P. (2001) "Theorizing the Influence of Media on World Politics". European Journal of Communication. Vol. 16(4).

[24] Sarantakos, S. (1998). Social research. Hampshire, London: Macmillian press. 